\title{
SISTEM MONITORING BEBAN LISTRIK BERBASIS ARDUINO NODEMCU ESP8266
}

\author{
Anggher Dea Pangestu', Feby Ardianto ${ }^{2}$, Bengawan Alfaresi ${ }^{3}$ \\ Jurusan Teknik Elektro, Fakultas Teknik, Universitas Muhammadiyah palembang \\ Program Studi Elektro, Fakultas Teknik, Universitas Muhammadiyah Palembang \\ *Corresponding author, e-mail: ardianto.feby@gmail.com
}

\begin{abstract}
Abstrak - Penggunaan daya listrik di rumah tangga selama ini hanya dapat dilihat melalui alat ukur $\mathrm{kWh}$ meter yang didistribusikan oleh PLN. Penggunaan alat tersebut tidak memberikan informasi tentang berapa besar daya listrik yang digunakan secara real-time. $\mathrm{kWh}$ meter hanya menunjukkan jumlah daya kumulatif yang terpakai. Oleh karena itu, diperlukan alat yang dapat memperlihatkan penggunaan daya listrik secara real-time, sehingga memudahkan penggunauntuk memantau konsumsi energi listrik. Tujuan penelitian adalah memonitoring beban listrik rumah tangga menggunakan arduino NodeMCU ESP8266 secara real-time. Metode yang digunakan dalam penelitian ini terdiri dari 4 tahapan, yaitu : 1). Pemilihan peralatan software dan hardware, 2). Perancangan sistem, 3). Pembuatan program, dan 4). Pengujian alat. Hasil dari pengujian alat menggunakan beban induktif berupa lampu LED 15 Watt sebanyak 2 buah dan beban resistif berupa setrika listrik yang diset pada titik panas maksimum, alat bekerja dengan baik dan mampu membaca besaran arus dan daya yang digunakan pada saat pengkondisian ON terhadap beban induktif dan beban resistif, tingkat akurasi alat dalam membaca berkisar $96 \%$ sampai dengan $98 \%$.
\end{abstract}

\section{Kata Kunci : Monitoring, NodeMCU ESP8266, LCD keypad shield, Sensor arus ACS712}

\begin{abstract}
The use of electric power in households so far can only be seen through a kWh meter measuring device distributed by PLN. The use of these tools does not provide information about how much electricity is used in real-time. $\mathrm{kWh}$ meter only shows the amount of cumulative power used. Therefore, a tool that can show the use of electric power in real-time is needed, making it easier for users to monitor electricity consumption. The research objective was to monitor household electrical loads using Arduino NodeMCU ESP8266 in real time. The method used in this study consists of 4 stages, namely: 1). Selection of software and hardware equipment, 2). System design, 3). Program making, and 4). Tool testing. The results of testing the tool using inductive loads in the form of 15 Watt LED lights as much as 2 pieces and resistive loads in the form of electric irons which are set at maximum heat points, the tool works well and is able to read the current and power used when ON to inductive loads and loads resistive, the level of accuracy of the tool in reading ranges from $96 \%$ to $98 \%$.
\end{abstract}

Keywords : Monitoring, NodeMCU ESP8266, LCD Keypad Shield, Current Sensor ACS712

\section{PENDAHULUAN}

Listrik merupakan kebutuhan wajib bagi manusia saat ini. Semua peralatan sebagian besar memakai listrik sebagai energinya. Kebutuhan akan listrik dari tahun ke tahun semakin besar, hal ini dikarenakan produsen juga semakin gencar memproduksi berbagai macam peralatan yang fungsinya beragam untuk membantu dan memenuhi kebutuhan manusia, mulai alat-alat elektronik rumah tangga, alat-alat kantor, industri, peralatan olah raga, serta peralatan yang lebih privasi lagi seperti smartphone dan lain sebagainya.

Penggunaan daya listrik di rumah tangga selama ini hanya dapat dilihat melalui alat ukur $\mathrm{kWh}$ meter yang didistribusikan oleh PLN. Penggunaan alat tersebut tidak memberikan informasi tentang berapa besar daya listrik yang digunakan secara real-time. kWh meter hanya menunjukkan jumlah daya yang kumulatif yang terpakai. Oleh karena itu, diperlukan alat yang dapat memperlihatkan 
penggunaan daya listrik secara real-time, sehingga memudahkan pengguna untuk memantau konsumsi energi listrik.

\section{TINJAUAN PUSTAKA}

\section{Monitoring}

Monitoring adalah proses rutin pengumpulan data dan pengukuran kemajuan atas objektif program. Memantau perubahan yang fokus pada proses dan keluaran. Monitoring akan memberikan informasi tentang status dan kecenderungan bahwa pengukuran dan evaluasi yang disediakan berulang kali dari waktu ke waku, pemantauan umumnya dilakukan untuk tujuan tertentu, untuk memeriksa proses terhadap suatu objek atau untuk mengevaluasi kondisi atau kemajuan menuju tujuan hasil manajemen atas efek tindakan dari beberapa jenis tindakan untuk mempertahankan manajemen yang sedang berjalan [1].

Secara umum monitoring bertujuan mendapatkan umpan balik bagi kebutuhan program proses pembelajaran yang sedang berjalan, dengan mengetahui kebutuhan ini pelaksanaan program akan segera mempersiapkan kebutuhan dalam pembelajaran tersebut. Kebutuhan bias berupa biaya, waktu, personel, dan alat. Pelaksanaan program akan mengetahui berapa biaya yang dibutuhkan, berapa lama waktu yang tersedia untuk kegiatan tersebut. Dengan demikian akan diketahui pula berapa jumlah tenaga yang dibutuhkan, serta alat apa saja yang harus disediakan untuk melaksanakan program tersebut [1].

\section{Beban Listrik}

Beban listrik adalah segala sesuatu yang ditanggung oleh pembangkit listrik atau bisa disebut segala sesuatu yang membutuhkan tenaga/daya listrik. Dalam kehidupan sehari-hari contoh beban listrik adalah setrika, lampu listrik, television, dan kompor listrik [2].

Pada keseluruhan sistem, total daya jumlah semua daya aktif dan reaktif yang dipakai oleh peralatan yang menggunakan energi listrik. Jadi dalam penggunaan rumah tangga, total beban listrik adalah total semua daya yang dikonsumsi oleh peralatan listrik tersebut yang aktif, karena dalam kondisi mati peralatan tertentu tidak menggunakan daya listrik [2].

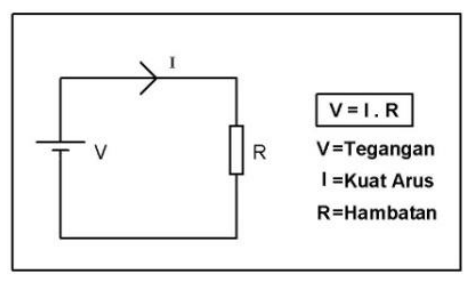

Gambar 1 Beban Arus Bolak-balik 
Beban listrik dikatakan juga sebagai hambatan/resistan (resistance) dalam ilmu listrik dimana dapat dirumuskan pada hukum ohm [3].

$$
V: I R
$$

Dengan:

$$
\begin{array}{ll}
I & : \text { Arus listrik dengan satuan Ampere } \\
R & : \text { Hambatan listrik dengan satuan ohm } \\
V & : \text { Tegangan listrik dengan satuan volt }
\end{array}
$$

Daya pada arus bolak-balik atau alternating current (ac) ada 3 macam yaitu daya aktif, daya reaktif dan daya nyata.

1. Daya aktif

Daya aktif digunakan secara umum oleh konsumen. Daya aktif inilah yang biasanya dapat dikonversikan dalam bentuk kerja. Satuan daya aktif dinyatakan dalam watt. Daya aktif (real power) [4], didapat dari persamaan.

$$
P=V \cdot I \cdot \cos \theta[k W]
$$

\section{Daya reaktif}

Daya reaktif adalah jumlah daya yang diperlukan untuk pembentukan medan magnet. dari pembentukan medan magnet. Maka akan terbentuk fluks magnet. Satuan daya reaktif dinyatakan dalam VAr. Daya reaktif (reactive power) [3], didapat dari persamaan:

$$
Q=V \cdot I \cdot \sin \theta[k V A]
$$

\section{Daya nyata}

Daya nyata adalah penjumlahan geometris dari daya aktif dan daya reaktif. Daya nyata merupakan daya yang diproduksi oleh perusahaan sumber listrik untuk diditribusikan ke konsumen, Satuan daya nyata ini dinyatakan dalam VA [3]. Daya nyata (apparent power),di dapat dari persamaan:

$$
S=V . I[k V A]
$$

Dengan :

$$
\begin{array}{ll}
\mathrm{P} & \text { :Daya Aktif }[\mathrm{kW}] \\
\mathrm{Q} & \text { :Daya Reaktif }[\mathrm{kVA}] \\
\mathrm{S} & \text { :Daya Nyata }[\mathrm{kVA}] \\
\mathrm{I} & \text { :Arus [Ampere] } \\
\mathrm{V} & \text { :Tegangan [Volt }]
\end{array}
$$

Hukum Ohm adalah suatu peryataan bahwa besar arus listrik yang mengalir melalui sebuah penghantar selalu berbanding lurus dengan beda potensial yang diterapkan kepadanya. Sebuah 
benda penghantar dikatakan mematuhi hukum Ohm apabila nilai resistansinya tidak bergantung terhadap besar dan polaritas beda potensial yang dikenakan kepadanya [3].

Ada dua jenis beban listrik berdasarkan sumbernya.

1. Beban listrik tegangan searah ; pada tegangan searah, semua beban adalah resistif (tidak ada pergeseran fase atau sudut ) maka rumus yang digunakan adalah rumus pada hukum ohm.

2. Beban listrik tegangan bolak-balik.

\section{NodeMCU ESP8266}

NodeMCU ESP8266 merupakan modul mikrokontroler yang didesain dengan ESP8266 di dalamnya. ESP8266 berfungsi untuk konektivitas jaringan Wifi antara mikrokontroler itu sendiri dengan jarigan Wifi. NodeMCU berbasis bahasa pemograman Lua namun dapat juga menggunakan Arduino IDE untuk prmogramannya [5]. Modul NodeMCU ESP8266 diperlihatkan pada gambar 2.

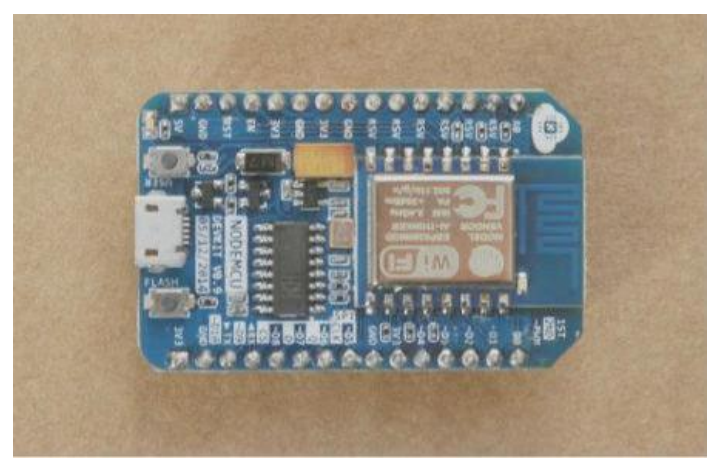

\section{Gambar 2 NodeMCU ESP8266}

Alasan pemilihan NodeMCU ESP8266 karena mudah deprogram dan memiliki pin I/O yang memadai dan dapat mengakses jaringan internet unuk mengirim atau mengambil data melalui koneksi WiFi [5]. Susunan kaki-kaki board NodeMCU ESP8266 diperlihatkan pada gambar 3.

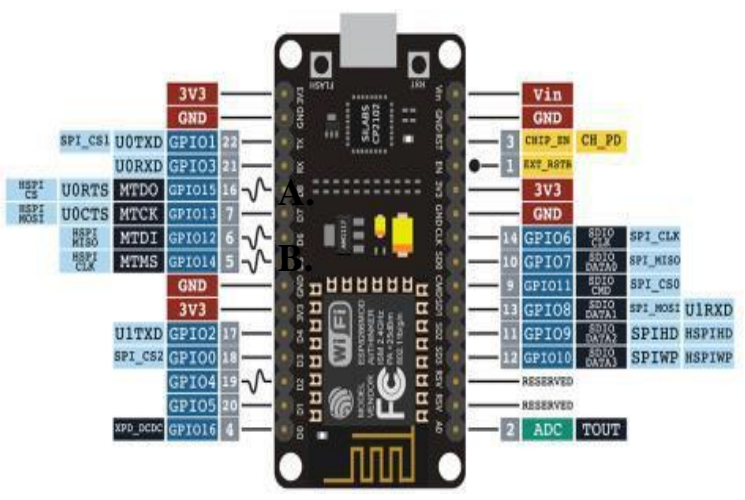

Gambar 3 Pinout NodeMCU ESP8266 


\section{Blynk}

Blynk merupakan aplikasi yang dirancang untuk Internet of Thinks (IoT). Aplikasi ini dapat digunakan untuk mengendalikan perangkat hardware, menampilkan data sensor, menyimpan data, visualisasi, dan lain lain [6].

Aplikasi Blynk memiliki 3 komponen utama, yaitu Aplikasi (App), Server, dan Libraries. Blynk erver berfungsi untuk menangani semua komunikasi diantara smartphone dan hardware. Jenis server bias menggunakan Blynk Cloud atau server sendiri (private). Widget yang tersedia pada Blynk diantaranya adalah Button, Value Display, History Graph, Twitter, dan Email [6]. Tampilan awal aplikasi Blynk diperlihatkan pada gambar 4.

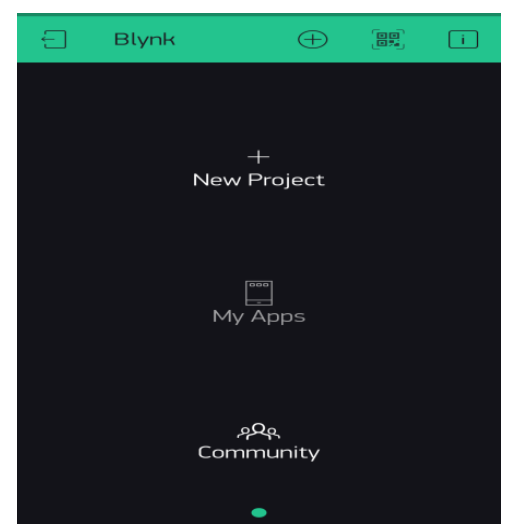

\section{Gambar 4 Tampilan Awal Aplikasi Blynk}

\section{METODE PENELITIAN}

\section{Diagram Fishbone}

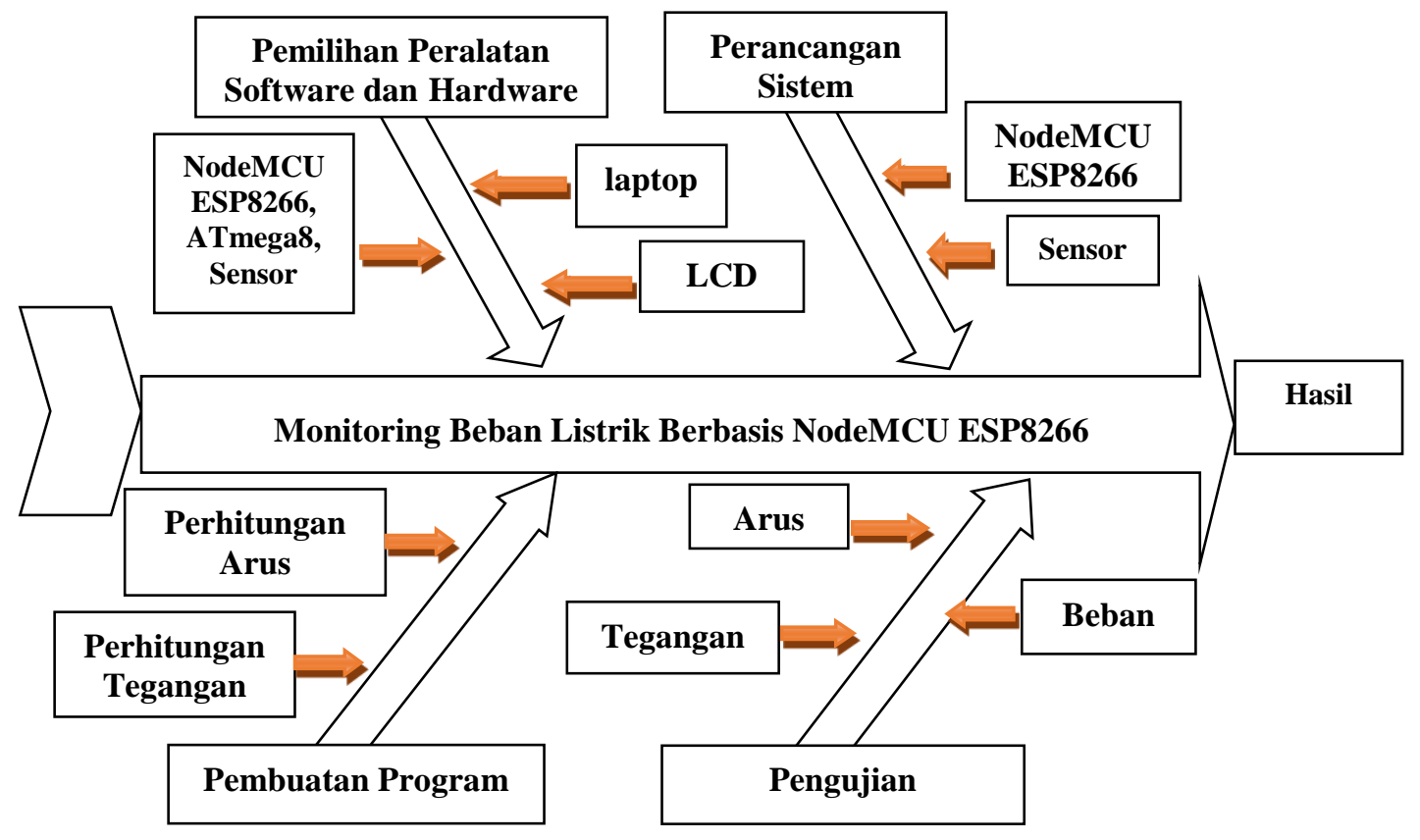

Gambar 5 Fishbone 
Tahapan Pertama Pemilihan Peralatan Software dan hardware, pada tahapan ini yang perluh di perhatikan yaitu apa saja perangkat software dan perangkat hardware yang akan digunakan untuk pembuatan rancang bangun alat pendeteksi beban listrik, mulai dari power supply, LCD untuk menampilkan hasil dari pengukuran beban yang akan diukur, dengan prosesan mengunakan NodeMCU ESP8266 dan yang terakhir sebagai alat input mengunakan sensor arus.

Tahapan kedua Perancangan Sistem atau desain, Hal pertama yang harus diperhatikan adalah pada saat penggabungan alat NodeMCU ESP8266, mulai dari pemasangan NodeMCU ESP8266 dengan Mikrokontroler tambahan ATmega8 sampai dengan sensor arus untuk dapat mengukur beban, hal ini di pasang satu persatu dan kemudian dicek, apakah bekerja atau tidaknya alat tersebut.

Tahapan ketiga Pembuatan Program, dimulai dari memprogram NodeMCU atau menyatukan NodeMCU dengan laptop, kemudian NodeMCU di sambungkan dengan input berupa sensor arus untuk mengukur arus, sebelum dapat diukur alat tersebut diprogram dengan software Arduino IDE.

Tahapan keempat pengujian alat, setelah selesai merancang dan memprogram alat NodeMCU dengan sensor arus, kemudian alat tersebut di uji meliputi pengujian sensor arus dengan 2 buah lampu sebagai beban utama, setelah pengukuran arus berhasil, kemudian hasil dari pengukuran akan ditampilkan di layar LCD keypad shield dan untuk membuktikan hasil pengukuran dapat diukur secara otomatis yang akan ditampilkan pada aplikasi Blynk.

\section{HASIL DAN PEMBAHASAN}

\section{Pengujian Tanpa Beban}

Tampilan hasil kondisi tanpa beban pada alat ditunjukkan pada gambar 6. Berdasarkan gambar 6, ditunjukkan bahwa hasil pengujian ketika alat tidak diberi beban maka alat tidak membaca besaran arus dan daya dikarenakan tidak ada beban yang terpasang pada

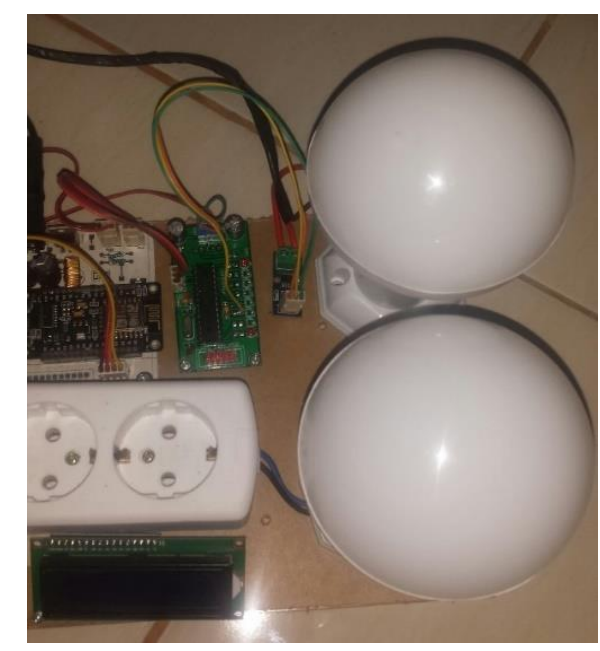

Gambar 6 kondisi Alat Ketika Tanpa Beban 
sistem, sedangkan nilai tegangan $220 \mathrm{~V}$ berasal dari sumber tegangan. Kondisi dan nilai tanpa beban ditunjukkan pada Tabel 1, dan Gambar 7 Menunjukkan grafik pada aplikasi Blynk saat kondisi tanpa beban.

Tabel 1 Kondisi Dan Nilai Tanpa Beban Yang Dimasukkan :

\begin{tabular}{|c|c|c|c|c|c|c|c|c|}
\hline \multirow[b]{2}{*}{ Beban } & \multicolumn{3}{|c|}{ Data Terpasang } & \multicolumn{3}{|c|}{ Data Pengukuran } & \multirow[b]{2}{*}{$\begin{array}{c}\text { Nilai } \\
\text { Selisih }\end{array}$} & \multirow[b]{2}{*}{ Akurasi } \\
\hline & $\begin{array}{c}\text { Arus } \\
\text { (A) }\end{array}$ & $\begin{array}{c}\text { Tegangan } \\
\text { (V) }\end{array}$ & $\begin{array}{c}\text { Daya } \\
(\mathrm{W})\end{array}$ & $\begin{array}{c}\text { Arus } \\
\text { (A) }\end{array}$ & $\begin{array}{c}\text { Tegangan } \\
\text { (V) }\end{array}$ & $\begin{array}{c}\text { Daya } \\
(\mathbf{W})\end{array}$ & & \\
\hline $\begin{array}{l}\text { Tanpa } \\
\text { beban }\end{array}$ & 0 & 220 & 0 & 0 & 220 & 0 & 0 & $100 \%$ \\
\hline
\end{tabular}

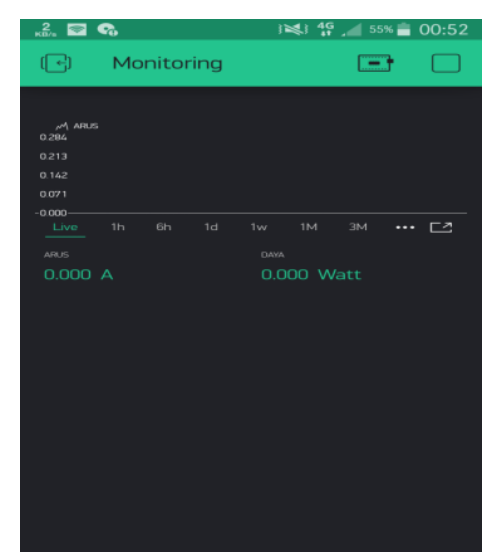

Gambar 7 Tampilan Grafik Pada Aplikasi Blynk Saat Kondisi Tanpa Beban

\section{Pengujian Menggunakan Beban Induktif}

Pengujian ini menggunakan beban induktif berupa lampu LED 15 Watt sebanyak 2 buah, dengan kombinasi salah satu lampu ON dan kedua lampu ON. Pengkondisian ON terhadap Beban Induktif untuk Lampu ke-1. Tampilan hasil pengkondisian ON terhadap beban induktif untuk Lampu ke-1, seperti ditunjukkan pada Gambar 8.

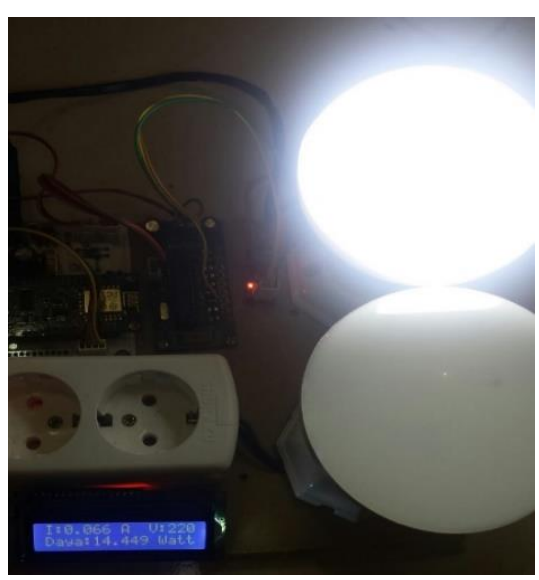

Gambar 8 Lampu Ke-1 Dinyalakan Dan Lampu Ke-2 Dalam Keadaan OFF 
Berdasarkan Gambar 8 ditunjukkan, bahwa hasil pengkondisian ON terhadap beban induktif untuk lampu ke-1 berupa pemberian sumber tegangan 220 Volt, maka lampu menyala dan tampilan pada layar $L C D$ menunjukkan besar arus, tegangan, dan daya yang digunakan pada saat lampu ke-1 dalam kondisi ON. Untuk lampu ke-2 dalam kondisi OFF dan lampu tidak menyala karena tidak terdapat tegangan. Nilai arus, tegangan, dan daya yang digunakan pada saat lampu ke-1 dalam keadaan ON dapat kita lihat pada Tabel 2, sedangkan Gambar 9 menunjukan grafik pada aplikasi Blynk ketika Lampu ke-1 diberi tegangan atau dalam keadaan ON dan lampu ke-2 dalam kondisi OFF.

Tabel 2 Nilai Arus Dan Daya Ketika Lampu Ke-1 Diberi Tegangan Atau Dalam Keadaan ON:

\begin{tabular}{|c|c|c|c|c|c|c|c|c|}
\hline \multirow[b]{2}{*}{ Beban } & \multicolumn{3}{|c|}{ Data Terpasang } & \multicolumn{3}{|c|}{ Data Pengukuran } & \multirow[b]{2}{*}{$\begin{array}{l}\text { Nilai } \\
\text { Selisih }\end{array}$} & \multirow[b]{2}{*}{$\begin{array}{l}\text { Tingkat } \\
\text { Akurasi }\end{array}$} \\
\hline & $\begin{array}{l}\text { Arus } \\
\text { (A) }\end{array}$ & $\begin{array}{c}\text { Tegangan } \\
\text { (V) }\end{array}$ & $\begin{array}{c}\text { Daya } \\
(\mathrm{W})\end{array}$ & $\begin{array}{l}\text { Arus } \\
\text { (A) }\end{array}$ & $\begin{array}{c}\text { Tegangan } \\
\text { (V) }\end{array}$ & $\begin{array}{c}\text { Daya } \\
(\mathbf{W})\end{array}$ & & \\
\hline 1 buah & & & & & & & & \\
\hline $\begin{array}{l}\text { Lampu } \\
\text { LED }\end{array}$ & 0.068 & 220 & 15 & 0.066 & 220 & 14.449 & 0.551 & $96,33 \%$ \\
\hline
\end{tabular}

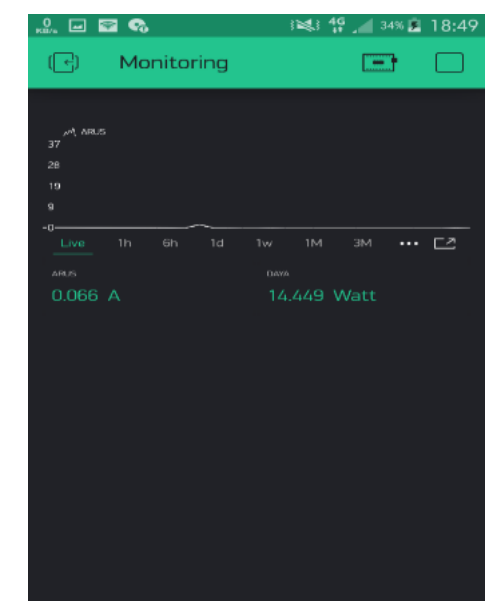

\section{Gambar 9 Tampilan Grafik Pada Aplikasi Blynk Ketika Lampu Ke-1 Diberi Tegangan Atau Dalam keadaan ON}

\section{Pengujian Menggunakan Beban Resistif}

Pengujian ini menggunakan beban resistif berupa setrika listrik 350 Watt yang diset pada titik panas maksimum. Pengkondisian ON terhadap beban resistif setrika 350 Watt. Tampilan hasil pengkondisian ON terhadap beban resistif setrika listrik, seperti ditunjukkan pada Gambar 10. 


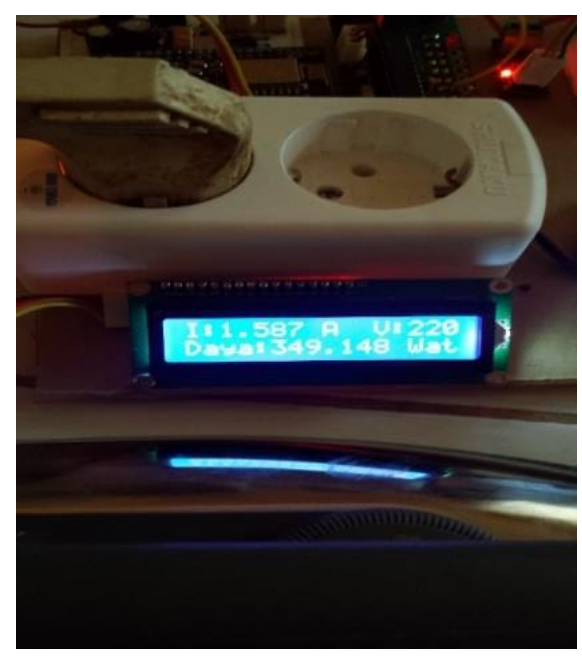

\section{Gambar 10 Pengkondisian ON Terhadap Beban Resistif Setrika listrik}

Berdasarkan Gambar 10 ditunjukkan bahwa, hasil pengkondisian ON terhadap beban resistif berupa setrika listrik dengan memasukkan tegangan sebesar 220 Volt, maka setrika listrik menyala dan tampilan pada layar LCD menunjukkan besar arus, tegangan, dan daya pada saat setrika dalam kondisi ON. Nilai arus, tegangan, dan daya yang digunakan pada saat setrika listrik diberi tegangan dapat kita lihat pada Tabel 3, dan Gambar 11 menunjukan grafik pada aplikasi Blynk ketika setrika listrik diberi tegangan atau dalam keadaan ON.

\section{Tabel 3 Nilai Arus Dan Daya Ketika Setrika Listrik Diberi Tegangan}

\section{Atau Dalam Kondisi ON :}

\begin{tabular}{|c|c|c|c|c|c|c|c|c|}
\hline \multirow[b]{2}{*}{ Beban } & \multicolumn{3}{|c|}{ Data Terpasang } & \multicolumn{3}{|c|}{ Data Pengukuran } & \multirow[b]{2}{*}{$\begin{array}{c}\text { Nilai } \\
\text { Selisih }\end{array}$} & \multirow[b]{2}{*}{$\begin{array}{l}\text { Tingkat } \\
\text { Akurasi }\end{array}$} \\
\hline & $\begin{array}{l}\text { Arus } \\
\text { (A) }\end{array}$ & $\begin{array}{c}\text { Tegangan } \\
\text { (V) }\end{array}$ & $\begin{array}{c}\text { Daya } \\
\text { (W) }\end{array}$ & $\begin{array}{l}\text { Arus } \\
\text { (A) }\end{array}$ & $\begin{array}{c}\text { Tegangan } \\
\text { (V) }\end{array}$ & $\begin{array}{l}\text { Daya } \\
(W)\end{array}$ & & \\
\hline $\begin{array}{l}\text { Setrika } \\
\text { Listrik }\end{array}$ & 1.590 & 220 & 350 & 1.587 & 220 & 349.148 & 0.852 & $99,75 \%$ \\
\hline
\end{tabular}

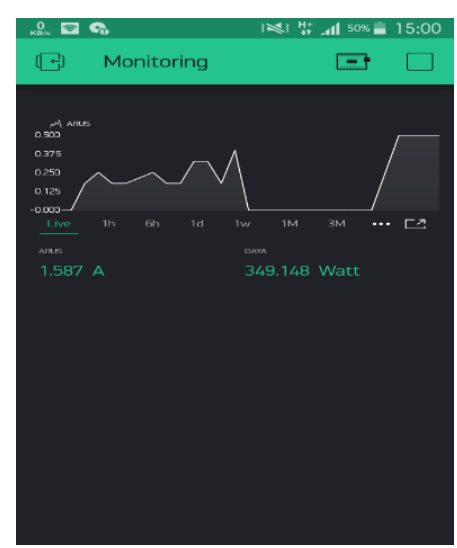

Gambar 11 Tampilan Pada Aplikasi Blynk Ketika Setrika Listrik Diberi Tegangan Atau Dalam Keadaan ON 


\section{Pengujian Kombinasi Beban Induktif Dan Beban Resistif}

Pengujian ini menggunakan beban induktif berupa lampu LED 15 Watt sebanyak 2 buah yang keduanya dinyalakan dan beban resistif berupa setrika listrik 350 Watt yang diset pada titik panas maksimum. Pengkondisian ON terhadap beban induktif 2 buah lampu 15 watt dan beban resistif setrika 350 Watt. Tampilan hasil pengkondisian ON terhadap beban induktif dan beban resistif, seperti ditunjukkan pada Gambar 12.

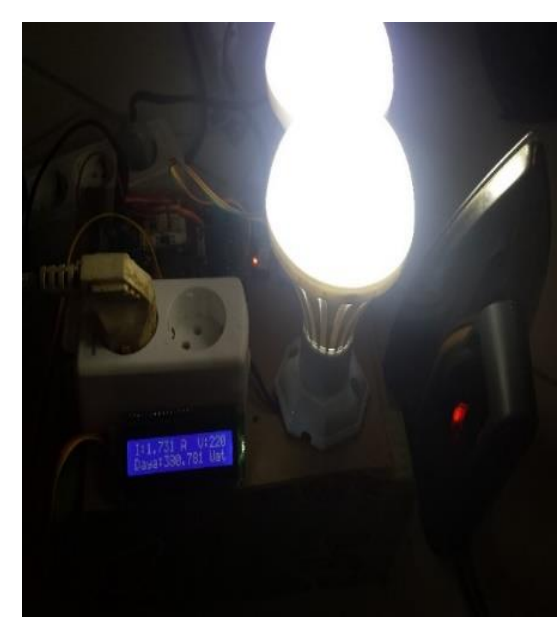

\section{Gambar 12 Pengkondisian ON Terhadap Beban Induktif \\ Dan Beban Resistif}

Berdasarkan Gambar 12 ditunjukkan bahwa, hasil pengkondisian ON terhadap beban induktif berupa 2 buah lampu LED dan beban resistif berupa setrika listrik dengan memasukkan tegangan sebesar 220 Volt, maka lampu LED dan setrika listrik menyala dan tampilan pada layar LCD menunjukkan besar arus, tegangan, dan daya pada saat lampu dan setrika dalam kondisi ON. Nilai arus, tegangan, dan daya yang digunakan pada saat beban induktif dan beban resistif diberi tegangan dapat kita lihat pada Tabel 4, dan Gambar 13 menunjukan grafik pada aplikasi Blynk ketika beban induktif dan beban resistif diberi tegangan atau dalam keadaan ON.

Tabel 4 Nilai Arus Dan Daya Ketika Beban Induktif Dan Beban Resistif Diberi

Tegangan Atau Dalam Kondisi ON :

\begin{tabular}{ccccccccc}
\hline \multirow{3}{*}{ Beban } & \multicolumn{3}{c}{ Data Terpasang } & \multicolumn{3}{c}{ Data Pengukuran } & Nilai & Tingkat \\
\cline { 2 - 6 } & $\begin{array}{c}\text { Arus } \\
(\mathbf{A})\end{array}$ & $\begin{array}{c}\text { Tegangan } \\
(\mathbf{V})\end{array}$ & $\begin{array}{c}\text { Daya } \\
(\mathbf{W})\end{array}$ & $\begin{array}{c}\text { Arus } \\
(\mathbf{A})\end{array}$ & $\begin{array}{c}\text { Tegangan } \\
(\mathbf{V})\end{array}$ & $\begin{array}{c}\text { Daya } \\
(\mathbf{W})\end{array}$ & $\begin{array}{c}\text { Selisih } \\
\text { Akurasi }\end{array}$ \\
\hline $\begin{array}{c}\text { Setrika } \\
\text { Listrik \& 2 } \\
\begin{array}{c}\text { Buah Lampu } \\
\text { LED }\end{array}\end{array}$ & 1.727 & 220 & 380 & 1.731 & 220 & 380.781 & 0.781 & $99,8 \%$ \\
\hline
\end{tabular}




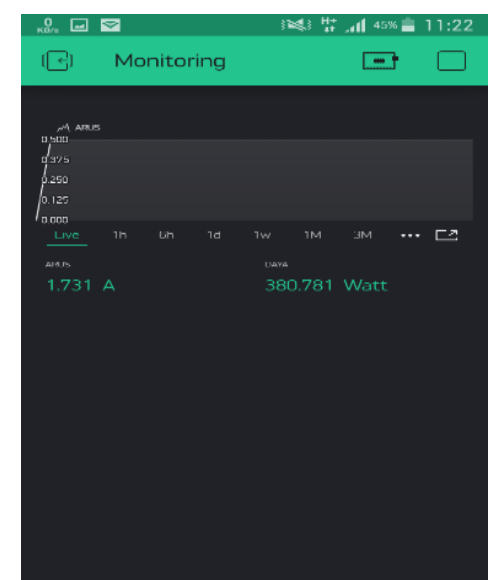

\section{Gambar 13 Tampilan Pada Aplikasi Blynk Ketika Beban Induktif Dan Beban Resistif Diberi Tegangan Atau Dalam Keadaan ON}

\section{KESIMPULAN}

Dari pengujian alat monitoring beban listrik dengan menggunakan beban induktif berupa lampu LED 15 Watt sebanyak 2 buah dan beban resistif berupa setrika listrik 350 Watt yang diset pada titik panas maksimum, alat bekerja dengan baik dan mampu membaca besaran arus dan daya yang digunakan pada saat pengkondisian ON terhadap beban induktif dan beban resistif, dan tingkat akurasi dari alat dalam membaca berkisar 96\% sampai dengan $99 \%$.

\section{DAFTAR PUSTAKA}

[1] Isnawaty, "Rancang Bangun Prototype System Monitoring Kelembaban Tanah Melalui SMS Berdasarkan Hasil Penyiraman Tanaman "Studi Kasus Tanaman Cabai dan Tomat"," Jurusan Teknik Informatika, Fakultas Teknik, Universitas Halu Oleo, Kendari, 2016.

[2] M. S. Budiawan, "Sistem Pengendali Beban Arus Listrik," Fakultas Saint dan Teknologi UIN Alauddin Makassar, Makassar, 2017.

[3] I. Dinata and W. Sunanda, "Implementasi Wereles Monitoring Energi Listrik Berbasis Web Database," Jurnal Nasional Teknik Elektro Volum: 4 No.1, p. 83, 2015.

[4] R. Sulistyowati and D. D. Febriantoro, "Perancangan Prototype Sistem Kontrol dan Monitoring Pembatas Daya Berbasis Mikrokontroler," IPTEK Vol.16 No.1, p. 25, 2012.

[5] H. D. Septama, "Smart Wirehouse: Sistem Pemantauan Dan Kontrol Otomatis Suhu Serta Kelembaban Gudang," Seminar Nasional Inovasi, Teknologi, dan Aplikasi (SeNTiA), p. 1, 2018.

[6] A. Wagyana, "Prototipe Smart Power Outlet Untuk Pencegah Kebakaran Akibat Arus Listrik," Prosiding SENTIA 2016, Politeknik Negeri Malang, pp. 89-90, 2016. 